\title{
Pluralistic ignorance: Conceptual framework, antecedents and consequences
}

\author{
Alcindo Mendes ${ }^{1}$ (D), Ernesto Lopez-Valeiras ${ }^{2}$ (D), Rogerio Joao Lunkes ${ }^{3}$ \\ ${ }^{1}$ Department of Administration and Accounting. Federal University of Viçosa (Brazil) \\ ${ }^{2}$ Accounting and Finance Department. University of Vigo (Spain) \\ ${ }^{3}$ Accounting Department. Federal University of Santa Catarina (Brazil) \\ alcindo.mendes@ufv.br,elvaleiras@uvigo.es,rogerio.lunkes@ufsc.br
}

Received May, 2017

Accepted July, 2017

\section{Abstract}

Purpose: The aim of this paper is to present, in an integrated manner, the knowledge acquired about pluralistic ignorance in the fields of social psychology, sociology and business. Particularly, to identify the factors that work as antecedents of pluralistic ignorance, as well as its consequences, in various research contexts.

Design/methodology: This integrative study on pluralistic ignorance was conducted with the Proknow-C method, which allows the construction of knowledge through a structured process of search and identification of a bibliographic portfolio.

Findings: The major results include the literature review and the identification of research networks such as Allport, O'Gorman, Shamir and Miller in the field social psychology and Harvey, Buckley and Halbesleben in organizations. A systemic analysis showed how pluralistic ignorance is formed, and clarified the difference between perceptual and inferential ignorance. The systemic analysis resulted in a model with seven social comparison errors that can be seen as antecedents of ignorance and a framework with its consequences, divided into three categories: people's attitude, people's behavior and organizational capabilities. 
Research limitations/implications: As with every research review, identification and review of the literature depend on the authors' world view. One of the difficulties in researching pluralistic ignorance is that it is studied in different areas of knowledge and from different perspectives.

Originality/value: The knowledge acquired throughout more than eight decades of research on pluralistic ignorance is fragmented into different perspectives. However, what was shown by the systemic analysis of the literature is that studies are more often geared toward psychosocial issues and it is still not very well known how the causes and consequences of pluralistic ignorance interact with the management processes in the organizational environment. This review presents a model for guiding the process of formation of pluralistic ignorance and a guiding framework for future research, as far as its consequences are concerned.

Keywords: Pluralistic ignorance, Attitude, Behavior, Organizational capabilities, Social comparison errors

Jel Codes: M10, M20, M40

\section{Introduction}

Pluralistic ignorance is a situation that occurs when an individual has a kind of attitude in public that is different from his individual beliefs because he mistakenly believes that most of his peers have an opposite opinion (Halbesleben, Wheeler \& Buckley, 2007; Prentice \& Miller, 1993; Miller \& McFarland, 1987). In social psychology and sociology, there is a great number of studies on pluralistic ignorance. Among other issues, pluralistic ignorance has been used to explain phenomena such as omission of assistance in emergency situations (Latane \& Darley, 1970), racial segregation (O'Gorman, 1975; 1979; Fields \& Shuman, 1976), or alcohol use by students (Prentice \& Miller, 1993; 1996; Schroeder \& Prentice, 1998).

Pluralistic ignorance has recently gained attention from researchers in the field of management, motivated by its ubiquity and by possible consequences for organizational performance (Buckley, Harvey \& Beu, 2000). Halbesleben et al. (2007), in a conceptual discussion, proposed a theoretical model indicating antecedent and consequent variables of pluralistic ignorance in organizational environments. In an empirical approach, Westphal and Bednar (2005), for example, showed that the existence of pluralistic ignorance in boards of directors led to inappropriate decisions. However, there 
is still no consolidated knowledge about empirical evidence for antecedents and consequences of pluralistic ignorance in organizations.

In this sense, this paper aims to undertake an integrative study which can represent the acquired knowledge about pluralistic ignorance in the psychosocial context, sociological and business literature. Specifically, it aims to provide an integrative framework by categorizing the antecedents and consequences of pluralistic ignorance. The antecedents are identified as seven social comparison errors: false consensus, exclusivity bias, third-person effect, vocal minority, group polarization, spiral of silence and social identity. In their turn, the consequences can be divided into three categories: people's attitude, people's behavior and organizational capabilities.

For this purpose, the Proknow-C method was used (Afonso, Souza, Ensslin \& Ensslin, 2011; Lunkes, Ripoll-Feliu \& Rosa, 2013; Valmorbida, Ensslin, Ensslin \& Ripoll-Feliu, 2014; Lacerda, Ensslin, Ensslin \& Dutra, 2014). This method allows the construction of knowledge through a structured process of search and identification of a representative bibliographic portfolio. This paper contributes to psychosocial, sociological and business literatures by shedding more light on the drivers and effects of pluralistic ignorance.

The paper is structured as follows: in addition to the introduction, the second section addresses the theoretical background about pluralistic ignorance, and explains its concepts and applications. Section three presents the methodology, and explains the steps used in the Proknow-C method. Section four presents and discusses the results for the representative bibliographic portfolio. Finally, section five makes some comments on the portfolio and gives suggestions for further research in the organizational context. 


\section{Pluralistic ignorance: Concept and classification}

Social norms are "shared patterns of thought, feeling and behavior" (Hogg \& Reid, 2006, pp. 8) that define people's collective attitudes and behaviors. There are multiple perspectives on the reasons why social norms emerge (Willer, Kuwabara \& Macy, 2009). From the point of view of functionalists, these rules emerge to harmonize the actions of society. By contrast, for utilitarians, social norms exist for the purpose of integrating social systems, while the theoreticians of conflict believe that norms are established to protect the interests of dominant relations.

The representation of these attitudes and behaviors are characterized as objective social norms. In the same way, individuals' perception of social norm can be defined as perceived social norms. When there is a discrepancy between the objective norm and the perceived norm, it means there is an error of assessment of the social norm by one or more individuals. As a result of poor perception of the objective norm, individuals may feel uncomfortable and change their attitudes toward the perceived norm (Prentice \& Miller, 1993). In some cases, this mistaken perception is not merely idiosyncratic, thus generating a collective movement toward the perceived norm. When this movement occurs collectively, it characterizes a situation of pluralistic ignorance.

In various social situations, people seek to understand the expectations and opinions of others so that they can take a stance themselves (Festinger, 1954). According to Fields and Schuman (1976), it is a consensus in social psychology that the actions of individuals will be influenced by such perception. Therefore, individuals seek to take a stance toward social norms.

Katz and Allport (1931) presented the term pluralistic ignorance for the first time in a study where they found that members of student fraternities would not accept new black members because they believed that this was the opinion of the majority, while individually they were contrary to racial segregation. Therefore, inaccurate judgment of the social norm caused a reversal of the illusion of universality, leading the group to a situation of pluralistic ignorance. Pluralistic ignorance, in the vision of Shamir and Shamir (1997), is a set of cognitive beliefs, shared by two or more people about ideas, feelings or actions of others.

Saito and Obushi (2014) differentiate between perceptual and inferential pluralistic ignorance. Perceptual pluralistic ignorance is considered to occur when one or more individuals agree on the objective social norm but they do not realize that there is an error of the norm. For example, an employee may not agree on going on strike, but as he mistakenly judges that the reasons for the strike are consistent with the opinion of the majority, although different from his individual convictions, he may approach the perceived norm. By contrast, inferential pluralistic ignorance occurs when people 
make a mistaken inference about the objective social norm, and in this case they tend to migrate their position toward the social norm. Based on the previous example, pluralistic ignorance would occur when, because of a mistaken inference, an employee believes that the majority of his colleagues wish to go on strike, and although he does not agree, he goes toward the perceived norm.

\section{Methodology}

To identify the fragment of the literature that represents the knowledge acquired about pluralistic ignorance, the constructivist Proknow- $\mathrm{C}$ method was used. The method aims to generate knowledge about a specific theme, so that the researcher will be able to select a set of available and relevant publications and identify research gaps. As reported by Afonso et al. (2011, pp. 48), in order to define the fragment of the literature, "it is essential that the researcher should not be misled by random paths, since this type of research requires a high degree of epistemological vigilance".

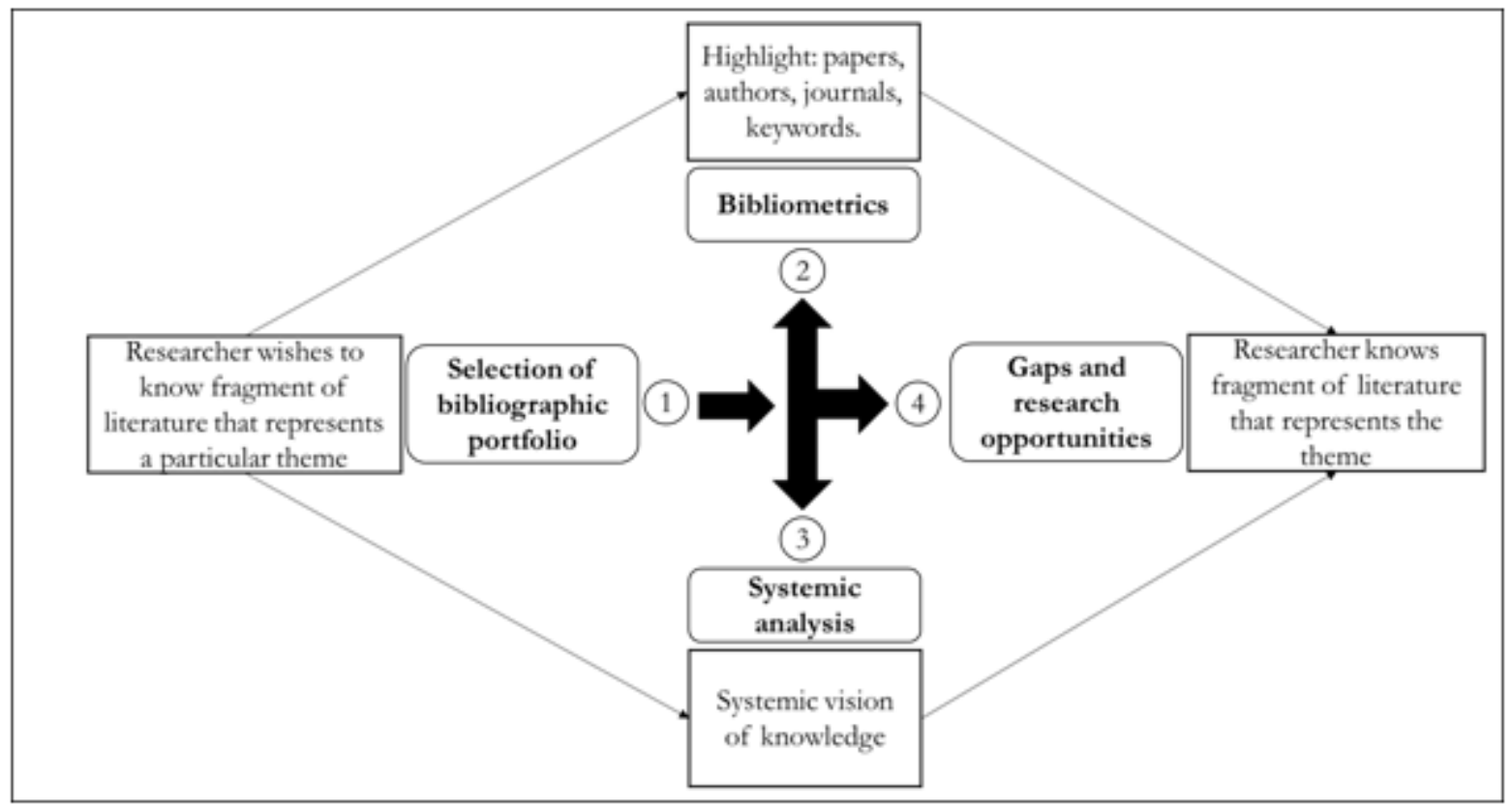

Figure 1. Stages of the structured process - Proknow-C (Valmorbida et al., 2014)

The method of investigation Proknow-C, as described in Figure 1, consists of four stages. In the first stage, the term "pluralistic ignorance" was used to identify the databases with the greatest number of papers. Subsequently, searches were performed in 6 databases, yielding a total of 1,329 papers, divided as follows: Web of Science (294), J-Stor (116), Science Direct (216), Wiley (441), Scopus (145) and PsicNet 
(117). Then, duplications were discarded, i.e., papers in more than one database, other types of documents and unavailable files, resulting in a portfolio of 928 papers.

Then, after the title and abstract of each paper were read, those aligned with the theme pluralistic ignorance were selected ( 74 of them). Finally, after full reading of the papers, 45 were selected; 31 of them fall in the field of social psychology-sociology and 14 in the field of business. The initial searches were made within the month of August 2016, without time constraints.

In the second stage, bibliometric analysis were made to identify certain characteristics in the evolution of the theme, such as the journals more closely related to the theme and papers more frequently referenced. In the third stage of Proknow-C, a systemic analysis was made, which is the reflective stage of the bibliographic portfolio. In this stage, the goal is to develop a reliable knowledge base and provide a critical evaluation of the research topic (Valmorbida et al., 2014).

\section{Results}

\subsection{Bibliometric analysis}

Figure 2 (designed with software Ucinet 6.0®) shows the connection network between authors of social psychology and sociology that have addressed pluralistic ignorance. The nodes highlighted in red are the authors with higher centrality in the network.

Thus, this analysis allows to identify three different epistemological milestones. First, Allport (1924) and Katz and Allport (1931) can be considered the starting point of studies on pluralistic ignorance.

Influenced by previous studies, the work of O'Gorman and colleagues can be considered the second epistemological milestone; they studied various situations involving pluralistic ignorance and racial segregation. The third milestone is formed by the work developed by Dale T. Miller and Debora A. Prentice. The works carried out by this group of research on student behavior have brought valuable contributions to empirical research methods. 


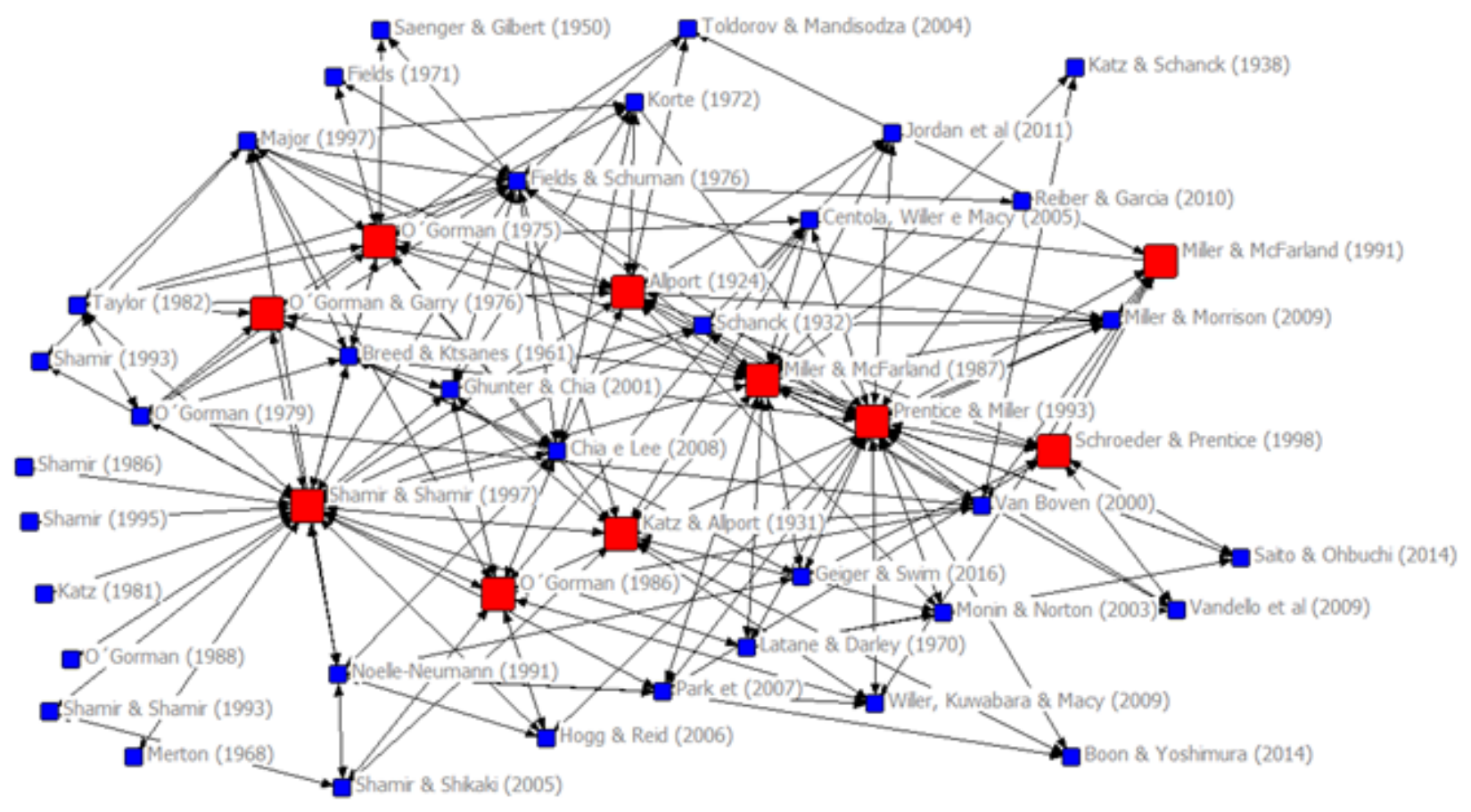

Figure 2. Network in the fields of social psychology and sociology

In business literature (see Figure 3), the most referenced works are Westphal and Bednar (2005) and Wenzel (2005). Although the two studies have great influence on the literature, importance should be noted for Michael Harvey, M. Ronald Buckley and Jonathon R.B. Halbesleben, who boosted publications about pluralistic ignorance. 


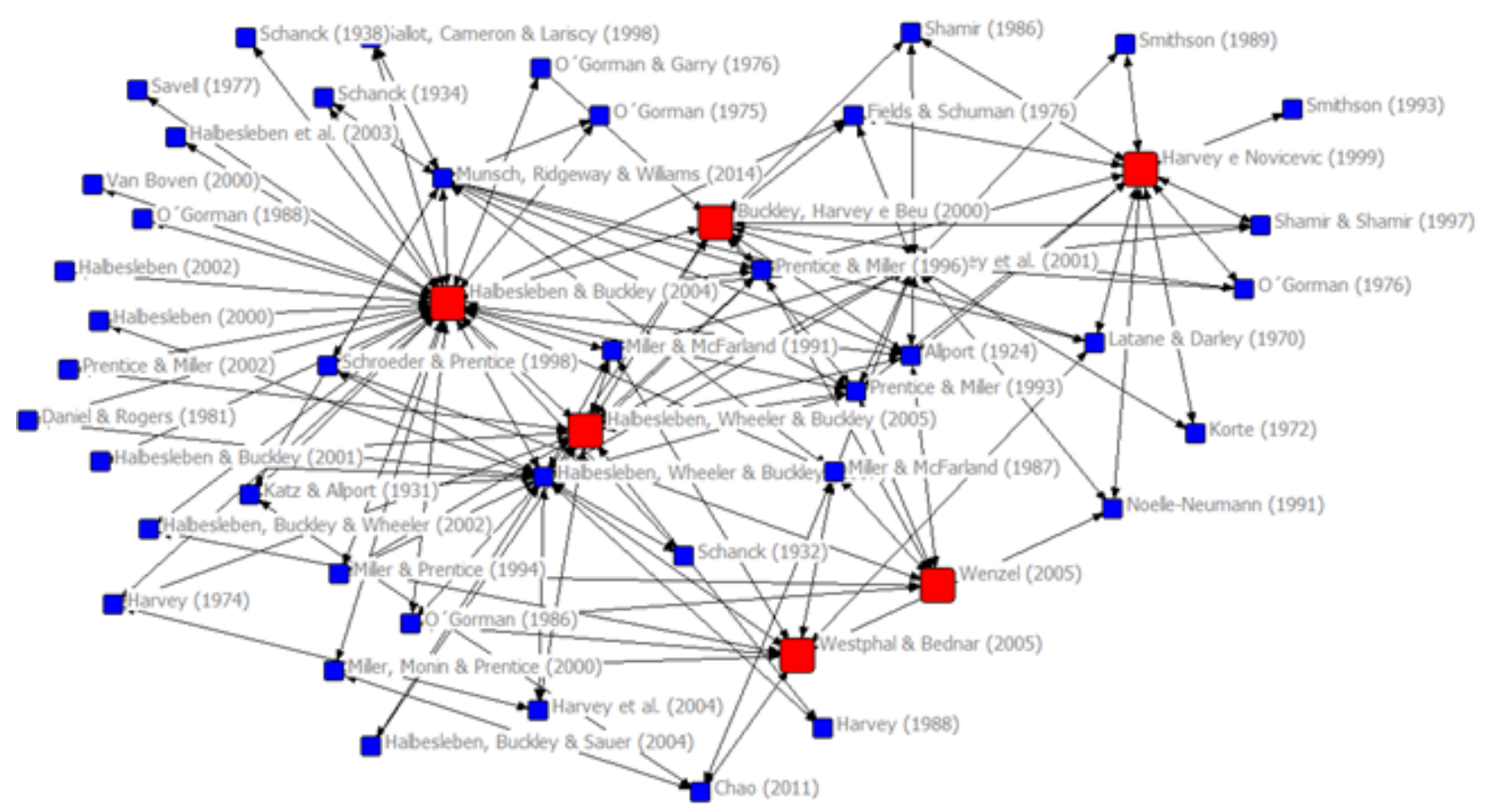

Figure 3. Network in the field of business

Among the papers of the bibliographic portfolio in the context of social psychology and sociology, the journal with the greatest number of publications was The Public Opinion Quaterly (6 papers). However, in the field of business, no single journal can be highlighted. Researchers more concerned with economics, for example, published in the Journal of Economic Psychology while management researchers published in Administrative Science Quarterly, Management Decision and other journals. Journals that seek to incorporate themes of psychology and management, e.g. the Journal of Managerial Psychology, were also interested in papers on this subject.

\subsection{Systemic analysis}

\subsubsection{Antecedents of pluralistic ignorance}

The antecedents pluralistic of ignorance were often related to the existence of social comparison errors (see Figure 4). In this sense, Social Comparison Theory indicates that when objective social norms are not clearly available, people search for ways to compare themselves with others to form their opinions and realize their abilities. As reported by Festinger (1954, pp. 117), "there exists, in the human organism, the drive to evaluate his opinions and his abilities." In this vision, it happens because people are seeking to minimize their differences when compared with the social group. Festinger (1954) also 
explains that as individual assessments are made while making social comparison, people take a stance as regards one another, thus forming social groups. However, when a social comparison error occurs, there can be a situation of pluralistic ignorance.

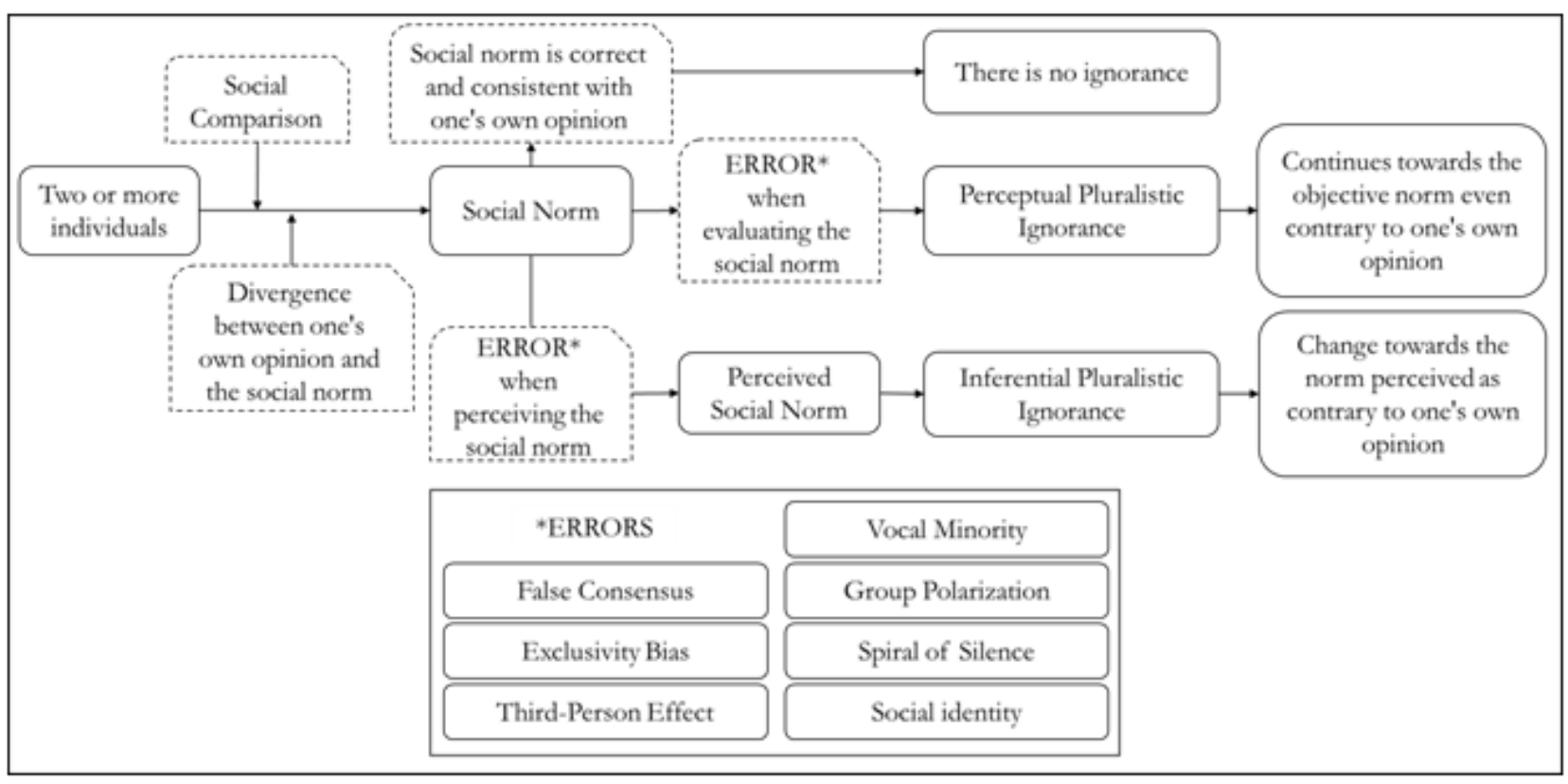

Figure 4. Process of formation of pluralistic ignorance

The literature review led to the identification of seven possible errors that can be considered as antecedents of pluralistic ignorance (see Figure 4). First, false consensus refers to a situation where an individual is inclined to overestimate how much other people agree with him (Miller \& McFarland, 1987). As explained by Gunther and Chia (2001), cognitive theories indicate that the search for consensus occurs because people tend to look at the facts and attitudes that resemble themselves more closely, while motivational theories suggest that people generally overstate the position that everyone agrees with them so as to legitimize their attitudes and thus improve their self-esteem.

Unlike false consensus, exclusivity bias is people's tendency to believe that they think differently from the majority (Goethals, Messick \& Allison, 1991; Monin \& Norton, 2003). In this case, people individually underestimate the opinions of others.

By contrast, the third-person effect refers to the influence exerted by a person outside the social group (Davison, 1983 apud Hogg \& Reid, 2006). The third-person effect is very frequently used in studies in which the media exert influence on the formation of the social norm. When this influence is perceived wrongly, it can generate pluralistic ignorance. 
Vocal minority suggests that when an individual gives his opinion, other people can take a different stance as they believe that this is the opinion of the majority, thus leading to pluralistic ignorance (Schank, 1932). In organizations, as employees tend to seek support in the opinion of leaders, they may take a minority opinion as a social comparison norm and, thus, cause the group to form a mistaken norm (Halbesleben et al. 2007).

Group polarization (e.g. Moscovici \& Zavalloni, 1969) argues that a social norm can be identified by the group only when there is polarization, i.e., when a stance is preferred over another. In this case, when there is no definition of the social norm, people analyze the opinions of other members of the group and will take a stance until an opinion of the majority establishes the norm. Pluralistic ignorance occurs when that majority is formed by a mistaken perception of the opinion of the majority.

In order for pluralistic ignorance not to be undermined, what is needed is the silence of the majority. Taylor (1982) sought another literature that deals with the spiral of silence theory (Noelle-Neumann, 1974) to check the reasons why the perception of the norm was maintained as inaccurate. The spiral of silence occurs when individuals believe they are a minority in their social environment. This helps to understand why people remain silent. Miller and Morrison (2009) found that the more the individual believes that his/her opinion differs from that of the majority, the greater the chance that he/she will remain silent. However, as he/she migrates to the perceived norm and feels comfortable, he/she is more likely to express his opinion publicly.

Finally, social identity (Turner, 1982; Tajfel \& Turner, 1986) suggests that people seek classifications between self and other (self-other) to maintain an identity within the social group. For example, people tend to classify a social group based on similar characteristics such as lawyers, women, teenagers, students, atheists, etc. In this case, individuals seek to share the same social values (O'Gorman, 1979). The relationship with pluralistic ignorance occurs because individuals defend ideas publicly in accordance with social identity, whereas they do not share this opinion individually.

\subsubsection{Consequences of pluralistic ignorance}

Figure 5 shows the conceptual framework that integrates the consequences of pluralistic ignorance in different contexts. These consequences can be classified into three broad categories: consequences on people's attitude, on people's behavior and on organizational capabilities. 


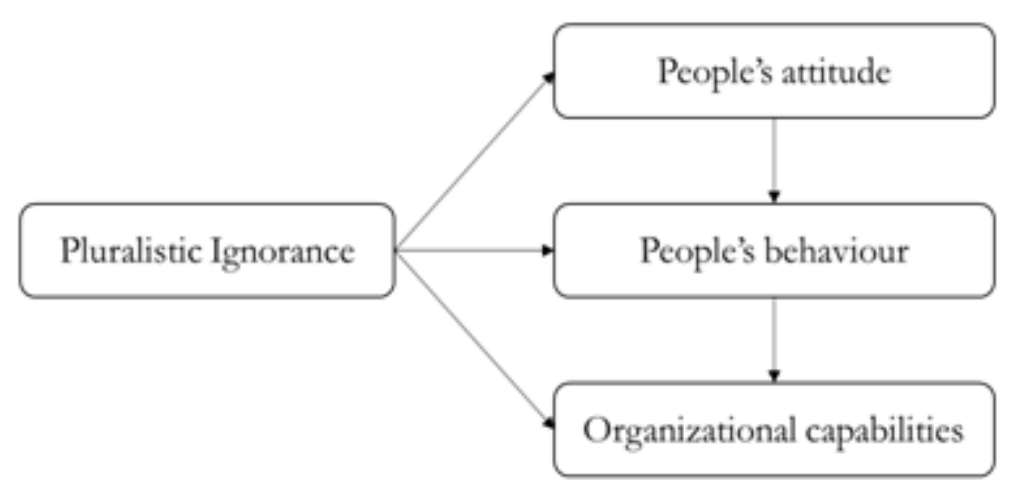

Figure 5. Conceptual framework of the consequences of pluralistic ignorance

On the one hand, in social psychology, attitudes are the basic individual personality processes that prompt an individual to act, perceive, think and feel towards objects and people (Curtis, 1960). Therefore, attitudes are internal habits that predict an individual's behavior. On the other hand, organizational skills are "intangible bundles of skills and accumulated knowledge exercised through organizational routines" (Gómez Conde, López-Valeiras Sampedro \& Ripoll F.eliu, 2013, pp. 392) that lead to a supported competitive advantage. Table 1 shows a collection of papers on the consequences of pluralistic ignorance, with their respective research methods and findings (the signs indicate the direction of the relationship). 


\begin{tabular}{|c|c|c|c|}
\hline Consequences & Works & Method & Result \\
\hline \multirow{10}{*}{ People's attitude } & Taylor (1982) & Survey & $\begin{array}{l}\text { Public opinion on pollution and nuclear } \\
\text { regulations }(+)\end{array}$ \\
\hline & Major (1997) & Survey & $\begin{array}{l}\text { Public opinion on alert in case of natural } \\
\text { disasters (-) }\end{array}$ \\
\hline & $\begin{array}{l}\text { Sallot, Cameron and Lariscy } \\
(1998)\end{array}$ & Survey & Recovery of professional standards (-) \\
\hline & $\begin{array}{l}\text { Hines, Saris and } \\
\text { Throckmorton-Belzer (2002) } \\
\text { Chia and Lee (2008) } \\
\text { Reiber and Garcia (2010) } \\
\end{array}$ & $\begin{array}{l}\text { Survey } \\
\text { Survey } \\
\text { Survey }\end{array}$ & Sexual Attitudes $(+)$ \\
\hline & $\begin{array}{l}\text { Ugarte, Rodríguez, Paz, Páez } \\
\text { and de Lucas (1998) }\end{array}$ & Survey & Prejudice against gypsies $(+)$ \\
\hline & Gunther and Chia (2001) & Survey & $\begin{array}{l}\text { Public opinion on the use of primates in } \\
\text { the laboratory }(-)\end{array}$ \\
\hline & $\begin{array}{l}\text { Todorov and Mandisodza } \\
(2004)\end{array}$ & Survey & $\begin{array}{l}\text { Public opinion on international policy } \\
\text { against terrorism (-) }\end{array}$ \\
\hline & Shamir and Shikaki (2005) & Survey & $\begin{array}{l}\text { Public opinion on separation between } \\
\text { Israel and Palestine }(+)\end{array}$ \\
\hline & Park and Yun (2007) & Survey & $\begin{array}{l}\text { Public opinion about the stereotype of } \\
\text { thinness of feminine beauty }(+)\end{array}$ \\
\hline & Geiger and Swim (2014) & $\begin{array}{c}\text { Survey/ } \\
\text { Experiment }\end{array}$ & Interest on climate issues (-) \\
\hline \multirow{11}{*}{$\begin{array}{l}\text { People's } \\
\text { behaviour }\end{array}$} & Korte (1972) & Survey & Student radicalism $(+)$ \\
\hline & $\begin{array}{l}\text { O'Gorman (1975; 1979) } \\
\text { Fields and Shuman (1976) }\end{array}$ & Survey & Racial Segregation (+) \\
\hline & $\begin{array}{l}\text { Prentice and Miller (1993) } \\
\text { Schroeder and Prentice } \\
(1998) \\
\text { Hines et al. (2002) } \\
\end{array}$ & $\begin{array}{l}\text { Experiment } \\
\text { Survey } \\
\text { Survey }\end{array}$ & Alcohol use $(+)$ \\
\hline & Hines et al. (2002) & Survey & Sexual Attitudes (+) \\
\hline & $\begin{array}{l}\text { Hines et al. (2002) } \\
\text { Smith-Simone, Curbow and } \\
\text { Stilman (2008) } \\
\end{array}$ & Survey & Smoking $(+)$ \\
\hline & Hines et al. (2002) & Survey & Illicit drug consumption $(+)$ \\
\hline & Monin and Norton (2003) & Survey & Use of water during a water crisis $(+)$ \\
\hline & Wenzel (2005) & Experiment & Tax evasion $(+)$ \\
\hline & $\begin{array}{l}\text { Vandello, Ransom, Hettinger } \\
\text { and Askew (2009) } \\
\text { Boon and Yoshimura (2014) }\end{array}$ & Survey & Male aggressiveness $(+)$ \\
\hline & Saito and Obuchi (2014) & Survey & Social Harmony $(+)$ \\
\hline & $\begin{array}{l}\text { Jordan, Monin, Dweck, } \\
\text { Lovett, John and Gross } \\
\text { (2011) }\end{array}$ & Experiment & $\begin{array}{l}\text { Sharing of negative feelings between } \\
\text { couples (-) }\end{array}$ \\
\hline \multirow{3}{*}{$\begin{array}{l}\text { Organizational } \\
\text { capabilities }\end{array}$} & $\begin{array}{l}\text { Buckley, Harvey and Beu } \\
(2000) \\
\text { Halbesleben, Wheeler and } \\
\text { Buckley (2005) }\end{array}$ & $\begin{array}{l}\text { Theoretical } \\
\text { Framework } \\
\text { Experiment }\end{array}$ & Unethical attitudes $(+)$ \\
\hline & $\begin{array}{l}\text { Harvey and Novicevic (1999; } \\
2000)\end{array}$ & $\begin{array}{l}\text { Theoretical } \\
\text { Framework }\end{array}$ & $\begin{array}{l}\text { Errors in the strategy of } \\
\text { internationalization }(+)\end{array}$ \\
\hline & Westphal and Bednar (2005) & Experiment & Persistence Strategy $(+)$ \\
\hline
\end{tabular}

Table 1. Consequences of pluralistic ignorance 


\section{People's attitude}

Several studies have shown the influence on people's attitudes. In this sense, Taylor (1982) found that there was a discrepancy in the opinion of residents of an American city about economic benefits, air pollution and the nuclear activities of a certain company. Individually, residents were against nuclear activities and against pollution caused by the company. However, they did not give their opinion because they believed that the majority had the opposite view.

Likewise, Major (1997) found that the perception of credibility of news about prevention of earthquakes was influenced by pluralistic ignorance. In this case, the lack of credibility of the media, due to the excess of false information, made people believe, at the individual level, that they should take action in the face of the news, but they believed that the majority would have no attitude. This led to an error of perception of the objective norm.

Sallot, Cameron and Lariscy (1998) found that pluralistic ignorance caused divergence of opinion about the professional norms of public relations professionals. Individually, they believed they were highly appreciated and responsible, thus underestimating the opinion of most people. Thus, as to professional norms, the belief was that most of their colleagues would not follow them correctly.

Chia and Lee (2008) found that students from Singapore overestimated sexual attitudes as they believed that their peers were significantly more active than they were. This poor perception of the social norm had a negative effect, causing students to indiscriminately increase the amount of sexual relations on campus. Similarly, Reiber and Garcia (2010), in a study with students in the USA, found that men and women believed that their peers were more comfortable with sexual practices without any commitment, than with their individual feelings.

In a study on negative attitudes against gypsies, Ugarte et al. (1998) found evidence that although people do not individually agree with these attitudes, they believed that most people have prejudice against them. For this reason, they did not express an unfavorable attitude in public for fear of a negative evaluation of the social group.

Gunther and Chia (2001) identified pluralistic ignorance as regards public opinion on the use of primates for research in the laboratory. They found that although only one fourth of the sample was contrary to the use of primates, in general they believed that the majority of the population would be contrary to this opinion.

Based on a public survey in the United States, Todorov and Mandisodza (2004) found that after the terrorist attacks of September 11, 23\% of respondents believed that the US should fight against 
terrorism alone, regardless of international support. However, they believed that $50 \%$ of Americans think differently. This situation characterizes pluralistic ignorance, because there is a poor perception of the opinion of the majority.

As to foreign policy, Shmair and Shikaki (2005) found that although Palestinians and Israelis agree on a national identity for each one of them, there was a discrepancy regarding the perception of public opinion. For example, $52 \%$ of Palestinians were favorable to the identity of each country, but they believed that only $32 \%$ would have that opinion, while $65 \%$ of Israelis agreed on the mutual identity, but they believed that only $36 \%$ would have that opinion.

In recent decades, the stereotype of thinness for feminine beauty has substantially affected women's eating habits in various parts of the world. A study by Park and Yun (2007) with academics showed that the media has a strong influence on this situation, and women overestimate the stereotype because of pluralistic ignorance.

As far as climate issues are concerned, many people believe, individually, that it is very important to discuss measures to be taken for preservation of the environment. However, the majority of these people remain silent. There is, therefore, a socially constructed silence as reported by Geiger and Swim (2014) on the basis of pluralistic ignorance. This means that the perception about the opinion of the majority is that there is no interest in discussing weather conditions.

\section{People's behavior}

Secondly, pluralistic ignorance may influence people's behavior, especially deviant behavior. Thus, Korte (1972) investigated the effect of pluralistic ignorance on student radicalism. Using a sample of American students of psychology, the author realized that in issues such as the Vietnam War, quality of teaching, illicit drug use and sex before marriage, there were situations involving pluralistic ignorance. The observation was made by means of variance tests, which showed discrepancy between students' responses and individual opinions, and also between individual opinions and the opinion on the majority.

O'Gorman (1975) found that although public opinion about racism in the USA had changed in the 1970s, social segregation still existed. This situation was explained by pluralistic ignorance, because although the individual opinion was against racial segregation, people's actions did not reflect this view because there was a bad public perception of this stance. O'Gorman (1975) found that the effect of pluralistic ignorance occurred evenly throughout the country, except in the South, where racial 
segregation seemed a little more intense. The author also realized that pluralistic ignorance was present, but it did not show significant differences for age, education or income.

Subsequently, Fields and Shuman (1976) found explanations about racist behavior on the basis of pluralistic ignorance in the city of Detroit (USA). In the research design, mothers of white children were asked if their children could play with black children in their home; the options of answers were:

- should not play;

- could play only at school;

- could bring them home to play.

The responses indicated a discrepancy between the objective norm and the perceived norm: individually, $76 \%$ of respondents did not see any problems in bringing black children at home to play with their children, but they believed that only $38 \%$ of their neighbors would agree on this opinion.

In another context, Prentice and Miller (1993) were worried about alcohol use by university students. Using a sample of undergraduate students, they found that there was clearly a situation of pluralistic ignorance, because the students believed that the majority felt more comfortable about alcohol use than they did themselves. The individual opinion about alcohol use was underestimated. The result of this poor perception was that pluralistic ignorance strengthened the increasing use of alcohol among students.

Later, Schroeder and Prentice (1998) conducted a study where they divided students into two groups. The first group received information about the influence of pluralistic ignorance on alcohol use, while the other group received only the traditional university orientation about healthcare on campus. They realized that the group that discussed the concepts of pluralistic ignorance had lower alcohol use over time.

Hines et al. (2002) used the same methodology of Prentice and Miller (1993), and found the same pattern of pluralistic ignorance with American students. In addition to alcohol use, the same behavior was found for smoking, use of illegal drugs and sexual behavior. Moreover, Hines et al. (2002) also found that pluralistic ignorance was greater when students were subjected to greater influence from the media, e.g., movies and TV series. As regards cigarette smoking, Smith-Simone, Curbow and Stillman (2008) found that there were differences between products, and that psychosocial factors such as pluralistic ignorance was decisive in increasing the consumption of a given product. This study is interesting because it indicated that pluralistic ignorance could be used as a strategy by the tobacco industry. 
Monin and Norton (2003) also found that there was a false consensus among American students during a period when they were advised not to have a shower in the light of a water crisis caused by a hurricane. It was found that students who were taking a shower despite the warning believed that the others did the same. In this case, there was pluralistic ignorance when people having a shower believed that they cared less about the community than about what they believed the opinion of the majority was.

Wenzel (2005) found that, although people may believe that they must pay their taxes correctly, they believe that most people practice tax evasion. In this case, pluralistic ignorance turns evasion into the perceived norm, thus influencing the decision of taxpayers.

Another behavior influenced by pluralistic ignorance, investigated by Vandello, Ransom, Hettinger and Askew (2009) with American students, was aggressiveness in men. In this case, men tend to overestimate the aggressiveness of their peers. In addition, men believe that women approve of this aggressive attitude. This poor perception of the social norm causes men to believe in the perceived norm. Similarly, Boon and Yashimura (2014), in a study with students in Canada, found that they believed that their peers saw vengeful attitudes more positively than they believed individually. The two studies have shown that pluralistic ignorance exerts a social effect, causing an increase in aggressiveness and vengeful attitudes.

However, pluralistic ignorance does not necessarily reflect adverse social consequences only. For example, Saito and Ohbuchi (2014) noted that in Japan, where society usually maintains strong values of social harmony, people tend to flee conflict, because they believe that the majority of people would do the same, i.e., avoid social conflicts. However, individually, the Japanese believe much less in the idea that they should avoid such conflicts. In this case, pluralistic ignorance favors the conservation of social harmony.

Jordan et al. (2011) found that people evaluate positive emotions of their peers compared with their own more accurately than they evaluate negative emotions. This shows that, in general, negative feelings tend to be more solitary than positive ones, and that is why people not only tend to omit but also to evaluate the social norm poorly. This poor perception of the norm toward negative feelings can generate consequences such as depression as a result of overestimating one's own suffering and underestimating the suffering of others. 


\section{Organizational capabilities}

Finally, pluralistic ignorance is also related to organizational capabilities. For example, when great scandals about organizational fraud occur, they raise questions about ethics. According to Buckley at al. (2000), although the media points to the increase of unethical attitudes in organizations, this statement needs to be better understood. The problem is that if the organizational culture leads workers to believe that unethical attitudes are a pattern of senior management, they will make a difference between the norm and the perceived norm. In this way, even if they do not agree individually, they will tend to approach the perceived norm. Buckley et al. (2000) suggest that people, in general, are more likely to believe that entrepreneurs are more likely to engage in unethical behavior than they are. For example, a former employee of Enron declared that, as he had never worked in another place, he began to believe that the unethical attitudes of their superiors were normal, although contrary to his individual values (Byrne et al., 2002 apud Halbesleben, Wheeler \& Buckley, 2005).

With students of a course in business ethics, Halbesleben et al. (2005) empirically tested if the discussion about pluralistic ignorance and the reduction of it increased the patterns of concepts about ethical attitudes. They found that students who participated in the discussions about pluralistic ignorance were less likely to engage in unethical issues in today's business environment. They also realized that when the concepts of pluralistic ignorance were discussed, there was a reduction in ignorance, as also found by Schroeder and Prentice (1998) for alcohol use at Princeton University. These results show that pluralistic ignorance is an important variable when the objective social norm is difficult to identify.

An important line of research was the works of Harvey and Novicevic (1999; 2000) involving pluralistic ignorance in global enterprises. Harvey and Novicevic (1999) noticed that managers often believed that attention to global markets was required, but as they saw no initiatives from senior management, they assumed that the company should not invest in global markets. Companies with strong organizational culture, such as IBM, Wal-Mart and Walt Disney, have failed in global enterprises by committing management errors which were subsequently related to Pluralistic Ignorance (Harvey \& Novicevic, 2000).

In one of the papers with the greatest impact, Westphal and Bednar (2005) found that, in case of low organizational performance, members of the board of directors tend to underestimate their concern for the current strategy and hence they do not publicly express their opinion at meetings. By using a sample of medium-sized public enterprises in the US, they confirmed that this is due to pluralistic 
ignorance. Moreover, they realized that demographic homogeneity, by means of variables such as gender and education, could reduce pluralistic ignorance.

\section{Conclusions}

The objective of this paper, through an integrative review of the literature, was to identify and analyze the knowledge acquired about pluralistic ignorance in the fields of social psychology, sociology and business. Particularly, it sought to identify and discuss the antecedents of pluralistic ignorance as well as its consequences in a variety of contexts presented for more than eight decades of research.

The Proknow-C method was used to identify a representative bibliographic portfolio of the subject, and a bibliographic analysis was made to highlight the most important authors in the knowledge network. The research conducted by the teams of Allport, O'Gorman, Shamir and Miller in social psychology and Harvey, Buckley and Halbesleben in business are central in the dissemination of the studies.

The systemic analysis clarified the formation of pluralistic ignorance and also the difference between perceptual pluralistic ignorance and inferential pluralistic ignorance. These two concepts are essential because future researchers should be aware that in one case the individuals follow the objective social norm, even though it is wrong (perceptual pluralistic ignorance) and in another case, they migrate toward the perceived norm (inferential pluralistic ignorance). Researchers on pluralistic ignorance in organizations are not usually bothered about this difference and this seems to be a drawback for pursuing further research.

Another important gap in research in the organizational context is the distinction between individual and collective consequences, as suggested in the model of Halbesleben et al. (2007). Although they have presented a model in 2007, organizational researchers have not yet explored these consequences empirically. For example, one does not know yet the effect of pluralistic ignorance in case of direct individual consequences such as the silence of the employee or the feeling of exclusion, nor in the case of indirect consequences such as stress or low commitment. Similarly, collective consequences such as weak organizational culture or high employee turnover rates have not been explored.

From the point of view of the causes of pluralistic ignorance in organizations, national culture has been proven in the studies of Harvey and Novicevic $(1999 ; 2000)$ as a key variable. Further research in this area is encouraged as nowadays companies have international relations or are affected in their markets on a global basis. 
In the area of strategy, many studies have shown that one of the difficulties in implementing a strategy is to align interests between managers and employees (Anthony, 1965; Otley, 1980; Chenhall, 2003). For this reason, many companies seek to implement control systems, which are not always successful as regards employee behavior (Merchant, 1985). In this sense, pluralistic ignorance may also serve as the basis to check lack of functionality in management control systems of organizations.

Although research on pluralistic ignorance has been conducted in the fields of social psychology and sociology for more than 80 years, it is still incipient in the realm of organizations. However, what can be seen is that, despite the difficulties inherent in applied research, the theme continues to awake the interest of business researchers. In fact, pluralistic ignorance seems to be related to various situations in the organizational context.

\section{References}

Afonso, M.H.F., Souza, J.V., Ensslin, S.R., \& Ensslin, L. (2011). Como construir conhecimento sobre o tema de pesquisa? Aplicação do processo proknow-c na busca de literatura sobre avaliação do desenvolviment o sustentável. Revista de Gestão Social e Ambiental, 5(2), 47-62. https://doi.org/10.24857/rgsa.v5i2.424

Allport, F. (1924). Response to social stimulation in the group. Social Psychology, 11, 260-291.

Anthony, R.N. (1965). Management Planning and Control Systems: A Framework for Analysis. Harvard Business School Press.

Boon, S.D., \& Yoshimura, S.M. (2014). Pluralistic ignorance in revenge attitudes and behavior in interpersonal relationships. Personal Relationships, 21(2), 258-271. https://doi.org/10.1111/pere.12030

Buckley, M., Harvey, M., \& Beu, D. (2000). The Role of Pluralistic Ignorance in the Perception of Unethical Behavior. Journal of Business Ethics, 23(4), 353-364. https://doi.org/10.1023/A:1006294002920

Byrne, J.A., France, M., \& Zellner, W. (2002, February 15). At Enron, the environment was ripe for abuse. Business Week Online, accessed November 22.

Chenhall, R. (2003). Management control systems design within its organizational context: Findings from contingency-based research and directions for the future. Accounting, Organizations and Society, 28(2-3), 127-168. https://doi.org/10.1016/S0361-3682(01)00027-7 
Chia, S.C., \& Lee, W. (2008). Pluralistic ignorance about sex: The direct and the indirect Effects of media consumption on College students' misperception of sex-related peer norms. International Journal of Public Opinion Research, 20(1), 52-73. https://doi.org/10.1093/ijpor/edn005

Curtis, J.H. (1960). Social psychology. New York: McGraw-Hill. https://doi.org/10.1037/13160-000

Davison, W.P. (1983). The third-person effect in communication. Public Opinion Quarterly, 47(1), 1-15. https://doi.org/10.1086/268763

Festinger, L. (1954). A Theory of Social Comparison Processes. Human Relations, 7(2), 117-140. https://doi.org/10.1177/001872675400700202

Fields, J.M., \& Schuman, H. (1976). Public Beliefs about Beliefs of the Public. Public Opinion Quarterly, 40(4), 427-448. https://doi.org/10.1086/268330

Geiger, N., \& Swim, J.K. (2014). Climate of silence: Pluralistic ignorance as a barrier to climate change discussion. Journal of Environmental Psychology, 47, 79-90. https://doi.org/10.1016/j.jenvp.2016.05.002

Goethals, G.R., Messick, D.M. \& Allison, S.T. (1991). The uniqueness bias: Studies of constructive social comparison. In J. Suls \& T. A. Wills (Eds.), Social comparison: Contemporary theory and research (pp. 149-176). Hillsdale, NJ: Lawrence Erlbaum Associates.

Gómez Conde, J., López-Valeiras Sampedro, E., Ripoll F.eliu, V., \& González Sánchez, M.B. (2013). Management control systems and ISO certification as resources to enhance internationalization and their effect on organizational performance. Agribusiness, 29(3), 392-405. https://doi.org/10.1002/agr.21300

Gunther, A.C. \& Chia, S.C. (2001). Predicting Pluralistic Ignorance: The Hostile Media Perception and its Consequences. Journalism \& Mass Communication Quarterly, 78(4), 688-701. https://doi.org/10.1177/107769900107800405

Halbesleben, J., Wheeler, A., \& Buckley, M. (2005). Everybody Else is Doing it, So Why Can’t We? Pluralistic Ignorance and Business Ethics Education. Journal of Business Ethics, 56(4), 385-398. https://doi.org/10.1007/s10551-004-3897-z

Halbesleben, J., Wheeler, A., \& Buckley, M. (2007). Understanding pluralistic ignorance in organizations: Application and theory. Journal of Managerial Psychology, 22(1), 65-83. https://doi.org/10.1108/02683940710721947

Harvey, M., \& Novicevic, M. (1999). The Trials and Tribulations of Addressing Global Organizational Ignorance. European Management Journal, 17(4), 431-443. https://doi.org/10.1016/S0263-2373(99)00023-7 
Harvey, M., \& Novicevic, M. (2000). Staffing Global Marketing Positions: What we don't know can make a difference. Journal of World Business, 35(1), 80-94. https://doi.org/10.1016/S1090-9516(99)00036-X

Hines, D., Saris, R.N., \& Throckmorton-Belzer, L. (2002). Pluralistic Ignorance and Health Risk Behaviors: Do College Students Misperceive Social Approval for Risky Behaviors on Campus and in Media?. Journal of Applied Social Psychology, 32(12), 2621-2640. https://doi.org/10.1111/j.15591816.2002.tb02760.x

Hogg, M.A., \& Reid, S.A. (2006). Social Identity, Self-Categorization, and the Communication of Group Norms. Communication Theory, 16(1), 7-30. https://doi.org/10.1111/j.1468-2885.2006.00003.x

Jordan, A.H., Monin, B., Dweck, C.S., Lovett, B.J., John, O.P., \& Gross, J.J. (2011). Misery Has More Company Than People Think: Underestimating the Prevalence of Others' Negative Emotions. Personality and Social Psychology Bulletin, 37(1), 120-135. https://doi.org/10.1177/0146167210390822

Katz, D., \& Allport, F. (1931). Student Attitudes. Syracuse: Craftsmen Press.

Korte, C. (1972). Pluralistic Ignorance About Student Radicalism. Sociometry, 35(4), 576-587. https://doi.org/10.2307/2786534

Lacerda, L.T.O., Ensslin, S.R., Ensslin, L., \& Dutra, A. (2014). A Constructivist Approach to Manage Business Process as a Dynamic Capability. Knowledge and Process Management, 21(1), 54-66. https://doi.org/10.1002/kpm.1428

Latane, B., \& Darley, J. (1970). The unresponsive bystander: Why doesn't he help?. New York: AppletonCentury-Crofts.

Lunkes, R.J., Ripoll-Feliu, V.M., \& da Rosa, F.S. (2013). Estudio de las Publicaciones sobre Contabilidad de Gestión en Brasil y España. Revista Contabilidade \& Finanças, 24(61), 11-26. https://doi.org/10.1590/S1519-70772013000100003

Major, A.M. (1997). Pluralistic ignorance and the climate of opinion in a real-time disaster prediction. International Journal of Public Opinion Research, 9(2), 170-190. https://doi.org/10.1093/ijpor/9.2.170

Merchant, K. (1985). Control in business organizations. CITY: Pitman.

Miller, D.T., \& McFarland, C. (1987). Pluralistic Ignorance: When Similarity is Interpreted as Dissimilarity. Journal of Personality and Social Psychology, 53(2), 298-305. https://doi.org/10.1037/00223514.53 .2 .298

Miller, D.T., \& Morrison, K.R. (2009). Expressing deviant opinions: Believing you are in the majority helps. Journal of Experimental Social Psychology, 45(4), 740-747. https://doi.org/10.1016/j.jesp.2009.04.008 
Monin, B., \& Norton, M.I. (2003). Perceptions of a Fluid Consensus: Uniqueness Bias, False Consensus, False Polarization, and Pluralistic Ignorance in a Water Conservation Crisis. Personality and Social Psychology Bulletin, 29(5), 559-567. https://doi.org/10.1177/0146167203029005001

Moscovici, S., \& Zavalloni, M. (1969). The group as a polarizer of attitudes. Journal of Personality and Social Psychology, 12(2), 125-135. https://doi.org/10.1037/h0027568

Noelle-Neumann, E. (1974). The spiral of silence: A theory of public opinion. Journal of Communication, 24(2), 43-51. https://doi.org/10.1111/j.1460-2466.1974.tb00367.x

O'Gorman, H.J. (1975). Pluralistic Ignorance and White Estimates of White Support for Racial Segregation. The Public Opinion Quarterly, 39(3), 313-330. https://doi.org/10.1086/268231

O'Gorman, H.J. (1979). White and Black Perceptions of Racial Values. The Public Opinion Quarterly, 43(1), 48-59. https://doi.org/10.1086/268490

Otley, D.T. (1980). The contingency theory of management accounting: Achievement and prognosis. Accounting Organizations and Society, 5(4), 413-428. https://doi.org/10.1016/0361-3682(80)90040-9

Park, S., \& Yun, G.W. (2007). Do Third-Person Perceptions of Media Influence Contribute to Pluralistic Ignorance on the Norm of Ideal Female Thinness?. Sex Roles, 57(7), 569-578. https://doi.org/10.1007/s11199-007-9284-3

Prentice, D.A., \& Miller, D.T. (1993). Pluralistic ignorance and alcohol use on campus: Some consequences of misperceiving the social norm. Journal of Personality and Social Psychology, 64(2), 243-256. https://doi.org/10.1037/0022-3514.64.2.243

Prentice, D.A., \& Miller, D.T. (1996). Pluralistic Ignorance and the Perpetuation of Social Norms by Unwitting Actors. Advances in Experimental Social Psychology, 28, 161-209. https://doi.org/10.1016/S00652601(08)60238-5

Reiber, C., \& Garcia, J.R. (2010). Hooking Up: Gender Differences, Evolution, and Pluralistic Ignorance. Evolutionary Psychology, 8(3), 390-404. https://doi.org/10.1177/147470491000800307

Saito, T., \& Obuchi, K. (2014). Who suffers pluralistic ignorance of conflict avoidance among Japanese?: Individual differences in the value of social harmony. International Journal of Conflict Management, 25(3), 261-275. https://doi.org/10.1108/IJCMA-04-2011-0033

Sallot, L.M., Cameron, G.T., \& Lariscy, R.A.W. (1998). Pluralistic ignorance and professional standards: Underestimating professionalism of our peers in public relations. Public Relations Review, 24(1), 1-19. https://doi.org/10.1016/S0363-8111(98)80017-9 
Schank, R.L. (1932). A study of community and its group institutions conceived of as behavior of individuals. Psychological Monographs, 43(2), 1-133. https://doi.org/10.1037/h0093296

Schroeder, C.M., \& Prentice, D.A. (1998). Exposing Pluralistic Ignorance to Reduce Alcohol Use Among College Students. Journal of Applied Social Psychology, 28(23), 2150-2180. https://doi.org/10.1111/j.1559-1816.1998.tb01365.x

Shamir, J., \& Shamir, M. (1997). Pluralistic Ignorance Across Issues and Over Time: Information Cues and Biases. The Public Opinion Quarterly, 61(2), 227-260. https://doi.org/10.1086/297794

Shamir, J., \& Shikaki, K. (2005). Public Opinion in the Israeli-Palestinian Two-Level Game. Journal of Peace Research, 42(3), 311-328. https://doi.org/10.1177/0022343305052014

Smith-Simone, S.Y., Curbowb, B.A., \& Stillman, F.A. (2008). Differing psychosocial risk profiles of college freshmen waterpipe, cigar, and cigarette smokers. Addictive Behaviors, 33(12), 1619-1624. https://doi.org/10.1016/j.addbeh.2008.07.017

Tajfel, H.C., \& Turner, J.C. (1986). The social identity theory of intergroup behavior. In S. Worchel \& W.G. Austin (Eds), Psychology of intergroup relations. Chicago: Nelson.

Taylor, G. (1982). Pluralistic Ignorance and the Spiral of Silence: A Formal Analysis. The Public Opinion Quarterly, 46(3), 311-335. https://doi.org/10.1086/268729

Todorov, A., \& Mandisodza, A.N. (2004). Public Opinion on Foreign Policy: The Multilateral Public That Perceives Itself as Unilateral. The Public Opinion Quarterly, 68(3), 323-348. https://doi.org/10.1093/poq/nfh036

Turner, J.C. (1982). Towards a cognitive redefinition of the social group. Social identity and intergroup relations. New York: Cambridge University Press.

Ugarte, I., Rodríguez, B., Paz, P.M., Páez, D., \& de Lucas, J. (1998). Ignorancia pluralista, atribución de causalidad y sesgos cognitivos en el caso. Revista de Psicología Social, 13(2), 321-330. https://doi.org/10.1174/021347498760350830

Valmorbida, S.M.I., Ensslin, S.R., Ensslin, L., \& Ripoll-Felliu, V.M. (2014). Avaliação de desempenho para auxílio na gestão de universidades públicas: análise da literatura para identificação de oportunidades de pesquisas. Contabilidade, Gestão e Governança, 179(3), 4-28.

Vandello, J.A., Ransom, S., Hettinger, V.E., \& Askew, K. (2009). Men's misperceptions about the acceptability and attractiveness of aggression. Journal of Experimental Social Psychology, 45(6), 1209-1219. https://doi.org/10.1016/j.jesp.2009.08.006 
Wenzel, M. (2005). Misperceptions of social norms about tax compliance: From theory to intervention. Journal of Economic Psychology, 26(6), 862-883. https://doi.org/10.1016/j.joep.2005.02.002

Westphal, J., \& Bednar, M. (2005). Pluralistic Ignorance in Corporate Boards and Firms Strategic Persistence in Response to Low Firm Performance. Administrative Science Quarterly, 50(2), 262-298. https://doi.org/10.2189/asqu.2005.50.2.262

Willer, R., Kuwabara, K., \& Macy, M.W. (2009). The False Enforcement of Unpopular Norms. American Journal of Sociology, 115(2), 451-490. https://doi.org/10.1086/599250

Intangible Capital, 2017 (www.intangiblecapital.org)

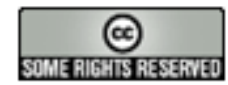

Article's contents are provided on an Attribution-Non Commercial 3.0 Creative commons license. Readers are allowed to copy, distribute and communicate article's contents, provided the author's and Intangible Capital's names are included. It must not be used for commercial purposes. To see the complete license contents, please visit http://creativecommons.org/licenses/by-nc/3.0/. 